\title{
The Brazil Current transport south of $23^{\circ} \mathrm{S}$
}

\author{
LOTHAR STRAMMA*
}

(Received 26 August 1988; in revised form 15 November 1988; accepted 30 November 1988)

\begin{abstract}
Geostrophic computations from historical data across the Brazil Current at $23^{\circ}$ and $24^{\circ} \mathrm{S}$ lead to transports of 10.2 and $9.6 \mathrm{~Sv}$, respectively. Data exist from all four seasons at about $24^{\circ} \mathrm{S}$, but no seasonal signal can be seen in the baroclinic transport of the Brazil Current there. At $33^{\circ} \mathrm{S}$ the Brazil Current transport is estimated to be $17.5 \mathrm{~Sv}$. A recirculation cell of $7.5 \mathrm{~Sv}$ is found in the western South Atlantic south of $28^{\circ} \mathrm{S}$. The major problem in computing transport of the Brazil Current is not with determining the correct reference depth, but with the Brazil Current flowing partially over the shelf and therefore not being sampled completely by deep-water hydrographic stations. As long as the vertical distribution of water masses is taken into account for choosing a reference depth, geostrophic computations lead to results consistent with previous estimates.
\end{abstract}

\section{INTRODUCTION}

THE Brazil Current has long been known to transport substantially less water than the Gulf Stream (STOMMEL, 1957), its counterpart in the North Atlantic, and, compared to the Gulf Stream, the Brazil Current has been sampled to a much lesser extent. Most transport estimates for the Brazil Current have been in two regions: near Rio de Janeiro and in the Brazil-Falkland Confluence Zone. At $19^{\circ} \mathrm{S}$ Miranda and Filho (1981) obtained a southward geostrophic volume transport of $5.5 \mathrm{~Sv}\left(1 \mathrm{~Sv}=10^{6} \mathrm{~m}^{3} \mathrm{~s}^{-1}\right)$ and a maximum surface velocity of $72 \mathrm{~cm} \mathrm{~s}^{-1}$, all relative to a layer near $500 \mathrm{~m}$ depth. Adjacent to Capo Frio at $24^{\circ} \mathrm{S}$, Signorini (1978) estimated the transport relative to $600 \mathrm{~m}$ as $9.4 \mathrm{~Sv}$, that being contained in two branches, with the peak surface geostrophic velocity as being $55 \mathrm{~cm} \mathrm{~s}^{-1}$. Within $60 \mathrm{~km}$ of that section, two other hydrographic sections yielded volume transports of 6.8 and $7.5 \mathrm{~Sv}$ by using the same reference of $600 \mathrm{~m}$ (SignORINI, 1978). Two other investigations in the area of $19^{\circ}$ to $24^{\circ} \mathrm{S}$ (Evans et al., 1983; EVANS and SigNorINI, 1985) agree with these estimates of transport and maximum surface velocity, using both direct current measurements and hydrographic data.

Gordon and GreEngrove (1986) investigated the Brazil-Falkland Confluence Zone, finding that at $38^{\circ} \mathrm{S}$ the Brazil Current transports $19 \mathrm{~Sv}$ southward relative to $1400 \mathrm{~m}$. Near that latitude, the Brazil Current encounters the northward-flowing Falkland (Malvinas) Current, and there both currents separate from the continental margin. The transport of $19 \mathrm{~Sv}$ toward the south at $38^{\circ} \mathrm{S}$ represents an increase of approximately $12 \mathrm{~Sv}$ over the transport at about $20^{\circ} \mathrm{S}$. The increase is less than that found for the Gulf Stream, but the $5 \%$ growth rate per $100 \mathrm{~km}$ is similar (GoRdon and GREENGROve, 1986). This

\footnotetext{
* Institut für Meereskunde, Düsternbrooker Weg 20, D 2300 Kiel, F.R.G.
} 


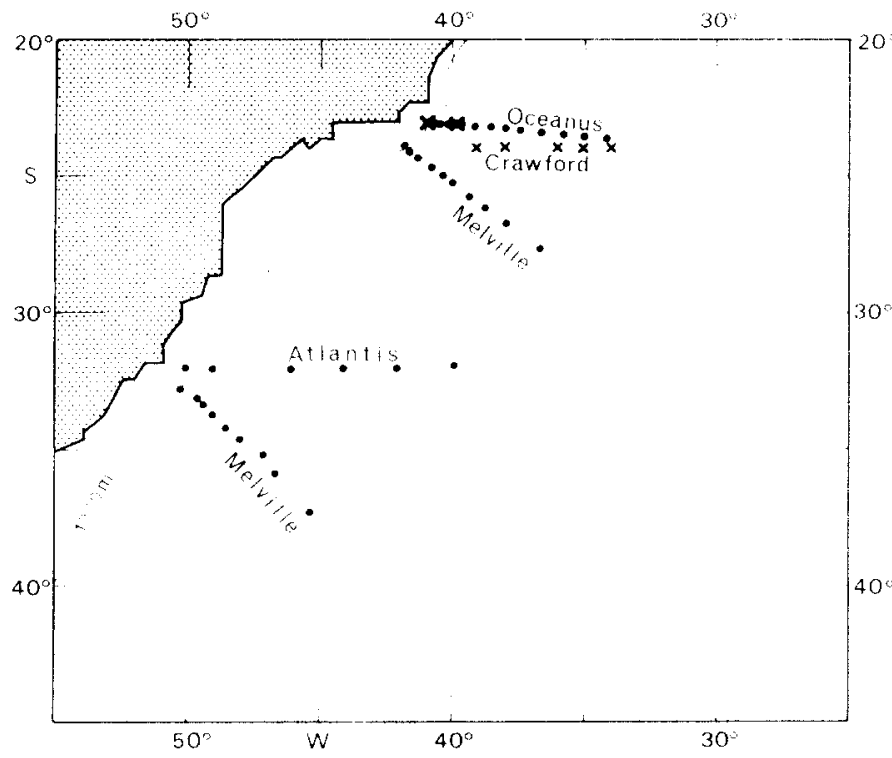

Fig. I. Hydrographic stations (dots or crosses) used for computing Brazil Current transports, together with ship names and the $1000 \mathrm{~m}$ isobath

increase may be associated with a recirculation cell in the South Atlantic. For latitudes between $24^{\circ}$ and $38^{\circ} \mathrm{S}$ there are apparently no direct transport estimates for the Brazil Current from hydrographic sections. Fu (1981), applying inverse methods to the transAtlantic IGY (International Geophysical Year) and R.V. Meteor hydrographic sections, obtained no clear Brazil Current north of $25^{\circ} \mathrm{S}$, but estimated it to have a transport of 20-27 Sv at $28^{\circ} \mathrm{S}$, which is large compared to other estimates.

In this study, geostrophic transports of the Brazil Current, relative to different reference depths, are estimated from the sections shown in Fig. 1. All data used here are archived at the World Oceanographic Data Center A (WODC, status 1988). Data near $24^{\circ} \mathrm{S}$ are used for comparisons with existing estimates while the other sections are presented to reduce the gap of transport estimates between $24^{\circ}$ and $38^{\circ} \mathrm{S}$. Finally, the upper geostrophic flow field of the western South Atlantic is constructed for November 1972, which again contributes to the transport estimates of the Brazil Current.

\section{TRANSPORT COMPUTATIONS}

The dynamic method for computing geostrophic velocities is burdened with the problem of finding an integration reference, commonly called the "level of no motion", a problem that is strongly dependent on the data available. Defant (1941) established reference depths on the basis of zero or low vertical gradients in geopotential anomaly. With the complete data set of the Meteor expedition of 1925-1927, as well as with other data, Defant (1941) estimated the best choice of a layer of no motion for the entire Atlantic Ocean. His reference depth for the South Atlantic ranges from $400 \mathrm{~m}$ at the equator to $2500 \mathrm{~m}$ in the central Atlantic near $50^{\circ} \mathrm{S}$. In the area of the Brazil Current he obtained a reference depth of $1300 \mathrm{~m}$ at about $23^{\circ} \mathrm{S}$, which descends to $1500 \mathrm{~m}$ at $28^{\circ} \mathrm{S}$ and $1800 \mathrm{~m}$ at $38^{\circ} \mathrm{S}$. Dynamic topography of the South Atlantic derived from his 
"surface-of-no-motion" clearly shows the gyre circulation, including the Brazil Current off the coast of Brazil (DEFANT, 1941).

More recently, investigations of the Brazil Current at $19^{\circ}$ to $24^{\circ} \mathrm{S}$ (Miranda and FilHo, 1981; SIgNORINI, 1978) have used reference depths between 500 and $600 \mathrm{~m}$, which are much shallower than Defant's. The $600 \mathrm{~m}$ depth lies between the surface layer, which flows to the south, and the Antarctic Intermediate Water, which flows to the north. The different flow directions can be seen in direct current velocity measurements made with a Pegasus profiler (Evans and Signorini, 1985). Therefore, a reference depth within the Antarctic Intermediate Water near $1000 \mathrm{~m}$ would lead to wrong transport estimates.

Transport estimates of the Brazil Current for the sections shown in Fig. 1, at various reference depths, are presented in Table 1. These transports are obtained by integrating velocities from the station nearest the coast out to where the upper ocean velocity vanishes or becomes northward. At station pairs not deep enough to reach the selected reference depth, the deepest depths available are used instead. At $23^{\circ}$ and $24^{\circ} \mathrm{S}$, using Defant's reference depth of $1300 \mathrm{~m}$, the Brazil Current transports increase by less than $1 \mathrm{~Sv}$ over those using a reference of $600 \mathrm{~m}$. The reason is that a $1300 \mathrm{~m}$ reference depth is located beneath the Antarctic Intermediate Water and within the Upper Circumpolar Deep. Water (REID et al., 1977), a layer probably having weak absolute motion. Therefore, using either Defant's reference depth or a $600 \mathrm{~m}$ depth leads to similar transports in the region $24^{\circ} \mathrm{S}$. The slightly smaller transports when using the lower transport integration depths at $800 \mathrm{~m}$ instead of $600 \mathrm{~m}$ is due to the influence of the northward-flowing Antarctic Intermediate Water below $600 \mathrm{~m}$. The Brazil Current is thus restricted to the upper $600 \mathrm{~m}$ near $24^{\circ} \mathrm{S}$.

In a survey of the Brazil Current between 19 and $24^{\circ} \mathrm{S}$, Evans and Signorini (1985) found it to be closely confined to the region near the continental slope. It flowed through the inshore-most passage of a seamount chain at $20^{\circ} 30^{\prime} \mathrm{S}$ and onto the continental shelf. From Pegasus profiler measurements at $24^{\circ} \mathrm{S}$ they estimated a Brazil Current transport of $11 \mathrm{~Sv}$, composed of $6 \mathrm{~Sv}$ offshore from the $200 \mathrm{~m}$ isobath and $5 \mathrm{~Sv}$ inshore. Their value of $11 \mathrm{~Sv}$ compares well with the transport estimates at $23^{\circ}$ and $24^{\circ} \mathrm{S}$ given in Table 1 , estimates made only with profiles in water depths of more than $500 \mathrm{~m}$.

The temperature section made by Oceanus at $23^{\circ} \mathrm{S}$ (Fig. 2a) shows strong horizontal gradients over the upper $600 \mathrm{~m}$ in the westernmost portions, those being related to the Brazil Current. The geostrophic velocity distribution for the western side of Fig. $2 a$ is

Table 1. Offshore transport estimates for the Brazil Current from historic profiles

\begin{tabular}{|c|c|c|c|c|c|}
\hline Ship & ${ }^{\circ} \mathrm{S}$ & Date & $\begin{array}{l}\text { Reference } \\
\text { depth (m) }\end{array}$ & $\begin{array}{l}\text { Integration } \\
\text { interval (m) }\end{array}$ & $\begin{array}{c}\text { Southward } \\
\text { transport (Sv) }\end{array}$ \\
\hline \multirow[t]{4}{*}{ Oceanus } & 23 & Feb. 1983 & 600 & $0-600$ & 10.2 \\
\hline & & & 600 & $0-800$ & 10.1 \\
\hline & & & $950 * / 1300$ & $0-600$ & 11.0 \\
\hline & & & $950 * / 1300$ & $0-800$ & 10.9 \\
\hline \multirow[t]{4}{*}{ Melville } & 24 & Nov. 1972 & 600 & $0-600$ & 9.6 \\
\hline & & & 600 & $0-800$ & 9.2 \\
\hline & & & $800 * / 1300$ & $0-600$ & 10.2 \\
\hline & & & $800^{*} / 1300$ & $0-800$ & 9.9 \\
\hline Atlantis & 32 & Apr. 1959 & $800^{*} / 1600$ & $0-800$ & $19.2(13.3)$ \\
\hline Melville & 33 & Nov. 1972 & $800 * / 1600$ & $0-800$ & 12.2 \\
\hline
\end{tabular}

* At coastal station pairs not deep enough to reach the selected reference depth, the deepest depth available, as indicated, was used instead. 


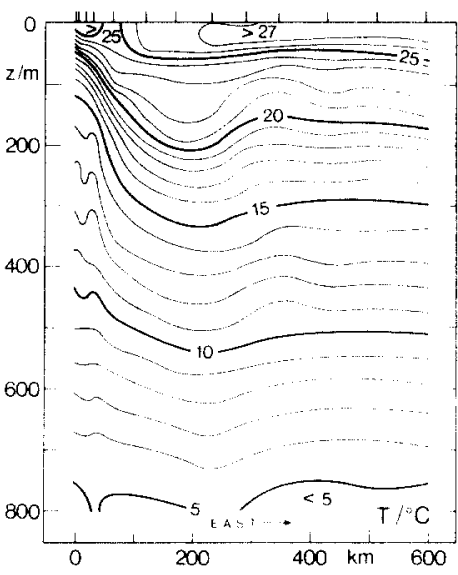

(a)

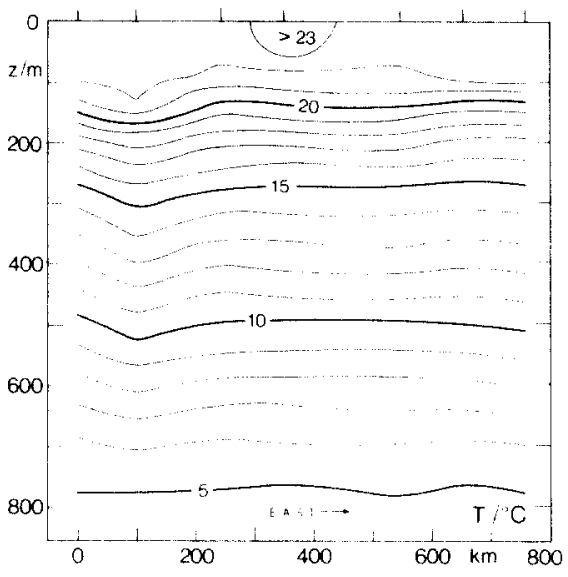

(b)

Fig. 2. Vertical sections of temperature as observed by (a) R.V. Oceanus in February 1983 between $23^{\circ} 2.3^{\prime} \mathrm{S}, 40^{\circ} 48.4^{\prime} \mathrm{W}$ (left) and $23^{\circ} 32.9^{\prime} \mathrm{S}, 35^{\circ} 1.0^{\prime} \mathrm{W}$ (right) and (b) R.V. Crawford in October 1958 between $23^{\circ} 5.4^{\prime} \mathrm{S}, 41^{\circ} 0.8^{\prime} \mathrm{W}$ (left) and $24^{\circ} 1.6^{\prime} \mathrm{S}, 34^{\circ} \mathrm{W}$ (right). Tick-marks on top indicate station positions.

presented in Fig. 3. The main core of the Brazil Current is found to have velocities of up to $58 \mathrm{~cm} \mathrm{~s}^{-1}$ at $50 \mathrm{~m}$ depth and velocities of more than $10 \mathrm{~cm} \mathrm{~s}^{-1}$ above $450 \mathrm{~m}$ depth. Another core to the west also has strong southward velocities, but they are limited only to the upper $100 \mathrm{~m}$. The inshoremost velocity profile has a surface speed of about $65 \mathrm{~cm} \mathrm{~s}^{-1}$, but because of the small cross-sectional area of this current band, it accounts for less than half Sverdrup out of the total southward Brazil Current transport of 10.2 Sv (Table 1).

The maximum speed of this Oceanus section compares well with that given by SIGNORINI (1978), with the $10.2 \mathrm{~Sv}$ transport obtained here being between the $9.4 \mathrm{~Sv}$ estimate of Signorini and the $11 \mathrm{~Sv}$ estimate of Evans and Signorini (1985), the latter having included the transport inshore of the $200 \mathrm{~m}$ isobath. Although no shelf transport is included in the computations made here at $23^{\circ} \mathrm{S}$ (Oceanus) and $24^{\circ} \mathrm{S}$ (Melville), indications are that the largest part of the Brazil Current transport was measured with these two sections.

Fu (1981) found the northernmost part of the Brazil Current to be at $16^{\circ}$ to $24^{\circ} \mathrm{S}$, further south than what is normally expected. A reason for this might be that $\mathrm{Fu}$ used the Crawford IGY section at $23^{\circ}$ to $24^{\circ} \mathrm{S}$ (Fig. 1). In contrast to the Oceanus section at $23^{\circ} \mathrm{S}$ (Fig. 2a), there is no strong signal of the Brazil Current in the Crawford temperature section (Fig. 2b). Geostrophic computations using the Crawford data lead to a southward transport of $2.5 \mathrm{~Sv}(0-600 \mathrm{~m}$ depth) between the two stations nearest the Brazilian coast, but this is compensated by a northward transport of $2.5 \mathrm{~Sv}(0-600 \mathrm{~m}$ depth) just to the east between Stas 2 and 3 counted from the west. The maximum velocity in the Crawford section, $8.4 \mathrm{~cm} \mathrm{~s}^{-1}$, is small compared to typical Brazil Current velocities of $50 \mathrm{~cm} \mathrm{~s}^{-1}$. The westernmost velocity profile of the Crawford section is located at the shelf edge, $21 \mathrm{~km}$ west of, and $6 \mathrm{~km}$ south of the westernmost profile of the Oceanus section at $23^{\circ} \mathrm{S}$. Therefore, the Brazil Current did not exist seaward of the 


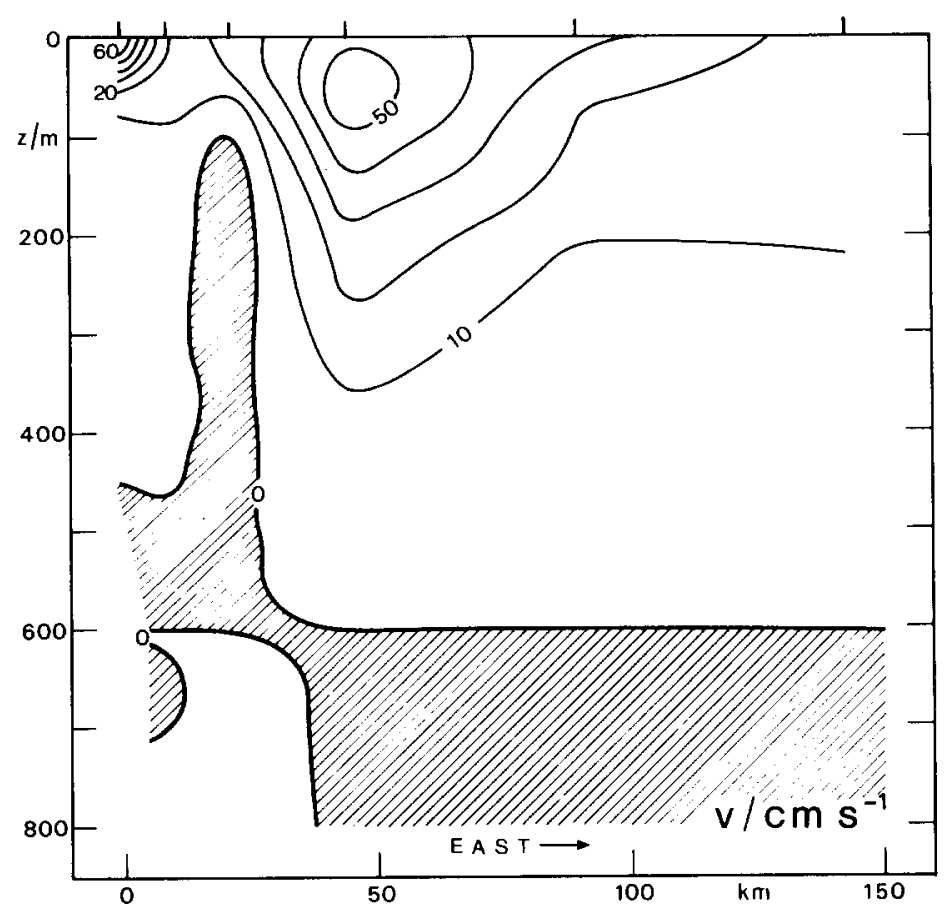

Fig. 3. Geostrophic velocity distribution relative to $600 \mathrm{~m} \mathrm{in} \mathrm{cm} \mathrm{s}^{-1}$ (positive southward, negative values are shaded and directed northward) for the Oceanus section in February 1983 between the stations at $23^{\circ} 2.3^{\prime} \mathrm{S}, 40^{\circ} 48.4^{\prime} \mathrm{W}$ (left) and at $23^{\circ} 11.7^{\prime} \mathrm{S}, 39^{\circ} 9.6^{\prime} \mathrm{W}$ (right). Tick-marks on top indicate the center between two stations.

$1000 \mathrm{~m}$ isobath in October 1958. Compared to the other sections presented here and in the literature near $23^{\circ} \mathrm{S}$, the Crawford section is the only one without a clear Brazil Current signal. From Evans and SigNORINI (1985) we know that a transport of at least $5 \mathrm{~Sv}$ can be found inshore of the $200 \mathrm{~m}$ isobath. Therefore it is not clear whether there was no Brazil Current at $23^{\circ} \mathrm{S}$ in October 1958 , or if the Brazil Current had shifted to the west of the $1000 \mathrm{~m}$ isobath and onto the shelf.

The Brazil Current flowing along the shelf edge, or on the shelf itself, might also be a problem in the transport estimates at $32^{\circ}$ and $33^{\circ} \mathrm{S}$ (Table 1). For these sections Defant's reference depth of $1600 \mathrm{~m}$ is used, which lies near the core of the Upper Circumpolar Deep Water (REID et al., 1977).

For the Atlantis IGY section at $32^{\circ} \mathrm{S}$ in April 1959, the two station pairs closest to the Brazilian coast show a transport of $19.2 \mathrm{~Sv}$ in the layer $0-800 \mathrm{~m}$ depth, but a strong reversal with a transport of $5.9 \mathrm{~Sv}$ to the north is found just to the east of those stations, which could reduce the transport to $13.3 \mathrm{~Sv}$ (Table 1). Evans et al. (1983) obtained a transport of $13 \mathrm{~Sv}$ at this Atlantis IGY section above $1000 \mathrm{~m}$, but did not explain how they derived it.

The Melville section at $33^{\circ} \mathrm{S}$, from the CATO expedition, gives a southward Brazil Current transport of $12.2 \mathrm{~Sv}$. The greatest velocity is $27 \mathrm{~cm} \mathrm{~s}^{-1}$ at the surface, and there are speeds of $10 \mathrm{~cm} \mathrm{~s}^{-1}$ or more above $620 \mathrm{~m}$ depth at the westernmost station pair. The western station is at the continental rise in about $850 \mathrm{~m}$ of water, so there is a strong possibility of significant transport west of this station. 
The CATO expedition by the Melville covered an area larger than just the Brazil Current region. Its quasi-synoptic survey extended out east of the Rio Grande Rise, and south of $40^{\circ} \mathrm{S}$. The transport field of the upper $800 \mathrm{~m}$ is computed here for that region of the western South Atlantic in November and December 1972. Defant's reference depths of $1300-1600 \mathrm{~m}$ are used. It is assumed that the transport of $9.9 \mathrm{~Sv}$ at $24^{\circ} \mathrm{S}$ (Table 1) represents the major transport of the Brazil Current, and that no significant transport occurred on the shelf. With this assumption the transports are computed along the sections and between stations of different sections. The resulting transport field (Fig. 4) shows a Brazil Current of $10 \mathrm{~Sv}$ close to the $1000 \mathrm{~m}$ isobath at $24^{\circ} \mathrm{S}$. South of $28^{\circ} \mathrm{S}$ a recirculation cell of $7.5 \mathrm{~Sv}$ is found which increases the Brazil Current transport to $17.5 \mathrm{~Sv}$ at $33^{\circ} \mathrm{S}$. There is a southward transport of $5 \mathrm{~Sv}$ west of the westernmost station at $33^{\circ} \mathrm{S}$, which is plausible from the velocity distribution described above. The Brazil Current transport of $17.5 \mathrm{~Sv}$ at $33^{\circ} \mathrm{S}$ agrees well with the slightly larger value of $19 \mathrm{~Sv}$ at $38^{\circ} \mathrm{S}$ given by GoRdon and GreEngrove (1986). The extension of the Brazil Current east of the Brazil-Falkland Confluence Zone can be seen in the lower portion of Fig. 4. GoRdon and GREENGROve (1986) noted that the Brazil Current becomes more diffuse in its extension to the east. PIOLA et al. (1987) computed the surface circulation of the southern world oceans from drifting buoys. While their surface velocity stream function for the South Atlantic shows an ocean-wide gyre with the center more to the South African side, the contours of large eddy kinetic energy in the western South Atlantic are very similar to the recirculation cell from the CATO expedition in Fig. 4.

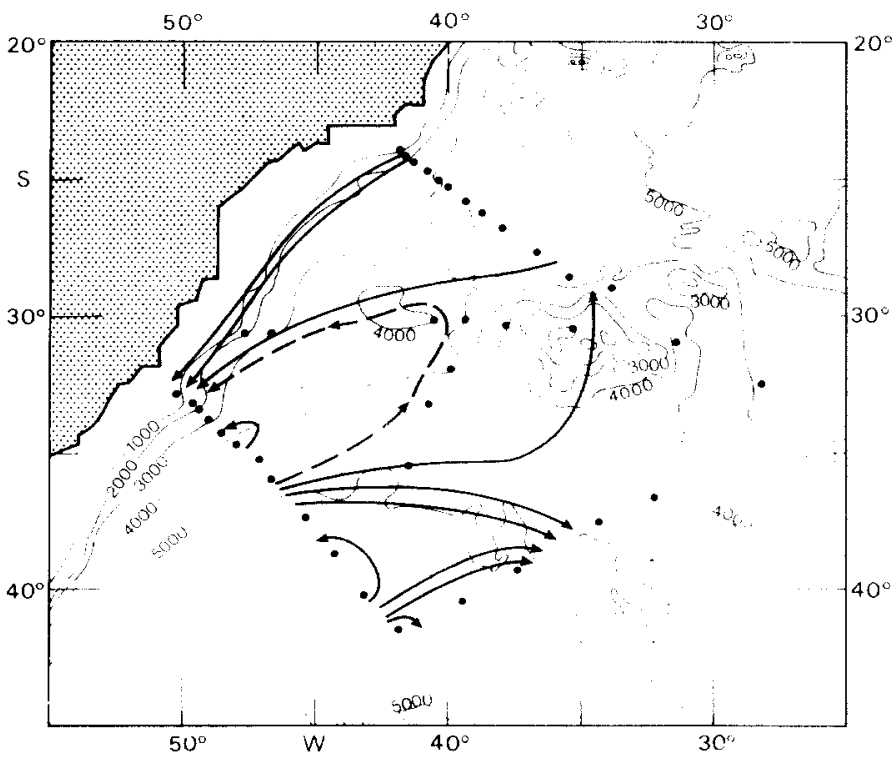

Fig. 4. Transport field of the CATO expedition profiles (dots) in November and December 1972 for the layer 0-800 m. Each flow line indicates $5 \mathrm{~Sv}$, the broken line $2.5 \mathrm{~Sv}$. Bathymetry is in meters (thin lines). 


\section{DISCUSSION}

A major problem in investigating the Brazil Current from particular hydrographic station data is that the current may at times be along the shelf edge, or even up on the shelf, whereas often the first station on hydrographic surveys is taken in deep water, therefore excluding the landward part of the transport. This is illustrated by the transport field of the CATO expedition (Fig. 4), where the computed balances lead to transports inshore of the $1000 \mathrm{~m}$ isobath. Transports of $10 \mathrm{~Sv}$ west of the section at $30^{\circ} 30^{\prime} \mathrm{S}$ and of $5 \mathrm{~Sv}$ west of the diagonal section in the south are found.

Among the water masses in the southwestern Atlantic is the Upper Circumpolar Deep Water (REID et al., 1977), which is where DEFANT's (1941) reference depth is located. This layer lies between the northward-flowing Antarctic Intermediate Water and the southward-flowing North Atlantic Deep Water, and should thus have weak absolute motion. Consequently, the choice of Defant's reference depth appears to lead to useful estimates of the Brazil Current transport. Near $24^{\circ} \mathrm{S}$, a reference depth at about $600 \mathrm{~m}$, which also lies between water masses moving in opposite directions, leads to transport values comparable to those obtained with Defant's reference. As long as the water mass distribution is taken into account in the choice of a reference depth, the offshore computations of the geostrophic transport of the Brazil Current lead to good results.

Still unclear is the reason for the absence of the Brazil Current in the Crawford IGY section at $23^{\circ} \mathrm{S}$ in October 1958. If there indeed was no current, it must be regarded as a rare occurrence of possible interannual variability, as several other investigations clearly showed a Brazil Current at this latitude. Evans and SignORINI's (1985) observations suggest that it might have shifted onto the shelf. Whatever the reason, it probably is not due to a seasonal signal. The CATO expedition took place in the same season as the Crawford section, but the CATO data give a strong Brazil Current at $24^{\circ} \mathrm{S}$. Furthermore, hydrographic sections taken at $23^{\circ}$ to $24^{\circ} \mathrm{S}$ in February (Oceanus, Table 1), in April (Evans and Signorini, 1985), in July (Signorini, 1978) and November (Melville, Table 1) of different years all lead to geostrophic transport values for the Brazil Current of 9-11 Sv, strongly suggesting that no large seasonal signal in the baroclinic transport of the Brazil Current at this latitude exists.

Acknowledgements-I thank R. G. Peterson for reviewing the manuscript. This work was supported by the BMFT Bonn, F.R.G., under grant 07 KF 2128 (VH12a).

\section{REFERENCES}

DEFANT A. (1941) Die absolute Topographie des physikalischen Meeresniveaus und der Druckflächen sowie der Wasserbewegungen im Raum des Atlantischen Ozeans. Wissenschaftliche Ergebnisse der deutschen atlantischen Expedition auf dem Forschungs- und Vermessungsschiff "Meteor" 1925-1927, 6, Teil 2, 5. Lieferung, pp. 191-260.

Evans D. L. and S. S. Signorini (1985) Vertical structure of the Brazil Current. Nature, 315, 48-50.

Evans D. L., S. R. Signorini and L. B. Miranda (1983) A note on the transport of the Brazil Current. Journal of Physical Oceanography, 13, 1732-1738.

FU L.-L. (1981) The general circulation and meridional heat transport of the subtropical South Atlantic determined by inverse methods. Journal of Physical Oceanography, 11, 1171-1193.

Gordon A. L. and C. L. GreEngrove (1986) Geostrophic circulation of the Brazil-Falkland Confluence. Deep-Sea Research, 33, 573-585.

Miranda L. B. and B. M. C. Filho (1981) Geostrophic flow conditions of the Brazil Current at $19^{\circ} \mathrm{S}$. Cienca Interamerica, 22, 44-48. 
Piola A. R., H. A. Figueroa and A. A. Bianchi (1987) Some aspects of the surface circulation south of $20^{\circ} \mathrm{S}$ revealed by First GARP Global Experiment drifters. Journal of Geophysical Research, 92, 5101-5114.

Reid J. L., W. D. Nowlin Jr and W. C. PATZERT (1977) On the characteristics and circulation of the southwestern Atlantic Ocean. Journal of Physical Oceanography, 7, 62-91.

SignoRINI S. R. (1978) On the circulation and volume transport of the Brazil Current between Cape of Sao Tome and Guanabara Bay. Deep-Sea Research, 25, 481-490.

Stommel H. (1957) A survey of ocean current theory. Deep-Sea Research, 4, 149-184. 